\title{
Concerns About Employment After Graduation: A Survey of First Professional Year Pharmacy Students
}

\author{
Jennifer Obi ${ }^{1}$, Ewanna Brown ${ }^{1}$, Essence Bell ${ }^{1}$ and Bisrat Hailemeskel*2 \\ ${ }^{1}$ Doctor of Pharmacy student, Howard University, NW Washington, USA \\ ${ }^{2}$ Professor \& Vice chair, Department of Clinical \& Administrative Pharmacy Sciences, College of Pharmacy, Howard University, \\ NW Washington, USA
}

*Corresponding author: Bisrat Hailemeskel, Professor \& Vice chair, Department of Clinical \& Administrative Pharmacy Sciences, College of Pharmacy,Howard University, NW Washington, DC, USA

\section{ARTICLE INFO}

Received: 慧April 22, 2021

Published: 豐 May 24, 2021

Citation: Jennifer Obi, Ewanna Brown, Essence Bell, Bisrat Hailemeskel. Concerns About Employment After Graduation: A Survey of First Professional Year Pharmacy Students. Biomed J Sci \& Tech Res 36(1)-2021. BJSTR. MS.ID.005790.

\begin{abstract}
The goal of this study is to assess the concern of first year pharmacy students of employment upon graduation. A 13-question survey was administered online to a total of 44 students with 100 percent participation. The data was collected and analyzed using SPSS statistical software. There were more female participants than males (Males $\mathrm{n}=10 ; 21.7 \%$ and Females $\mathrm{n}=34 ; 73.9 \%$ ) with mostly age range between $18-24$ years of age $(n=25 ; 54.3 \%)$. Majority of the student live outside the DMV area before joining the pharmacy program $(n=19 ; 41.3 \%)$. Most of the students have worked before getting admitted into the pharmacy program $(n=42 ; 91.3 \%)$ with the highest annual income earned was less than $\$ 10,000(n=17 ; 37 \%)$ with a job in a pharmacy or other healthcarerelated setting $(n=34 ; 73.9 \%)$. Over three-quarter of participants $(n=34 ; 75.5 \%)$ were very concerned about employment after graduation and close to seventy percent of participants $(n=31 ; 68.9 \%)$ believed that the pharmacy related job they desire to work is saturated. Significantly more female participants and those who live outside the DMV area before joining the pharmacy program at Howard were concerned about getting a job after they graduate. ( $\mathrm{F} \mathrm{n}=33.3 ; 97.8 \%$ vs $\mathrm{M} \mathrm{n}-7 ; 2.2 \% \mathrm{p}<0.001)$ ). Over sixty percent $(\mathrm{n}=29 ; 64.4 \%)$ of the students have a plan to or are currently working during pharmacy school to increase their chances of gaining employment after graduation. Overwhelming number of students ( $\mathrm{n}=32 ; 71.1 \%)$ are also willing to move anywhere and accept any pharmacy job to obtain employment if job opportunities are scares.
\end{abstract}

\section{Introduction}

In the $21^{\text {st }}$ century, the quality of education has tremendously improved, while the percentage of educated people increases. While this achievement has provided a positive impact on society, it has also brought about new challenges. One of the main challenges is the issue of employment after graduation. The rate of job creation has not increased proportionately with the increase in graduates graduating every year. As a result, the situation leads to a new social phenomenon where a growing number of graduates are increasingly becoming unemployed. The case is only likely to worsen under the current economic conditions further exacerbated by the coronavirus pandemic. The Michigan State's Collegiate
Employment Research Institute recently conducted a study on the recruiting trends in the current post-corona job market by surveying 2,408 employers. The researchers found that about $25 \%$ of the employers had suspended plans to recruit employees from colleges 2. A quarter of the respondents had also decided not to offer full-time positions to recent college graduates2. In 2020, the unemployment rate of young people aged between 15 and 24 sharply increased to $27.4 \%$ in April1 as the United States education stakeholders increase their efforts to ensure that the number of students graduating increases, there is a risk that the number of unemployed graduates is going to increase. Therefore, all education stakeholders need to come up with possible solutions to this 
problem. In recent years, there have been numerous discussions concerning the saturation of the pharmacy field after a period of unprecedented growth in pharmacy graduates and no subsequent dramatic expansion of pharmacist jobs. These discussions have led to considerable fear among many Pharm.D. candidates about acquiring quality employment.

Research from a study found, "Even if the job market is able to accommodate up to 12,000 graduates a year for the next several years, that still translates into at least 3,000 graduates each year who will not find suitable employment-20\% of the cohort of new graduates". According to this study, the decreased demand for pharmacists will negatively impact future Pharm.D. graduates because of the increased supply of pharmacists.

The concerns regarding pharmacy job availability have been documented, however, the subsequent fears that have arisen from said studies have not been addressed from a pharmacy students' perspective. The result of this study will help to determine the fears, if any, current pharmacy students have concerning job availability after graduation and their reasoning for their fear, or lack thereof. Therefore, the goal of this study is to have an opinion of pharmacy students during their first year of pharmacy on the possible of employment upon graduation.

\section{Methods}

A survey was done, and data were collected from 40 first-year students at Howard University College of Pharmacy. The survey consisted of 13 question. 8 of these questions were demographic based such as age, gender, before coming to Howard: annual income, previous job, job type, length of employment in years, highest education earned, and state lived while the remaining 5 questions were specific to the topic. The study variables were categorized based on concerns about employment after graduation, is the field saturated or not, will working while in pharmacy school increase chances of employment after graduation and willingness to move anywhere and accept any pharmacy job to obtain employment if job opportunities are sparse. The data was rated on a 5-point scale (strongly disagree to strongly agree). A descriptive statistic is done using SPSS statistical software. To measure statistical significance, the alpha was set to a level of 0.05 .

\section{Results}

This research survey consisted of 44 students with 100 percent response rate. There were more female participants than males (Males $n=10 ; 21.7 \%$ and Females $n=34 ; 73.9 \%$ ). The participants were mostly between the ages of $18-24$ years old ( $n=25 ; 54.3 \%)$. Majority of the student live outside the DMV area before joining the Howard University pharmacy program $(n=19 ; 41.3 \%)$ and the least number of the students live in DC $(n=4 ; 8.7 \%)$. Most of the students have worked before getting admitted into the pharmacy program ( $n=42 ; 91.3 \%)$ with the highest annual income earned was less than $\$ 10,000(n=17 ; 37 \%)$ and the least annual income earned was between $\$ 20,000$ to $\$ 29,000$ ( $n=3 ; 6.5 \%$ ). Majority of the students have a work experience in a pharmacy related setting $(n=27 ; 58.7 \%)$ while only a small number of students ( $n=7 ; 15.2 \%)$ worked in a Non-pharmacy-related or other health care related jobs. Finally, majority of the students have a previous job experience of about $1-3$ years $(n=14 ; 30.4 \%)$. Over half the participants $(n=26$; $56.5 \%)$ have a bachelor's degree and about one-quarter $(n=12$; $26.1 \%$ ) have some college degree with the least number of students having a 2-year degree $(n=4 ; 8.7 \%)$ (Table 1$)$.

Table 1: Demographics of participants.

\begin{tabular}{|c|c|}
\hline \multicolumn{2}{|c|}{ Gender of Participants } \\
\hline Female & $10(21.7 \%)$ \\
\hline Male & $34(73.9 \%)$ \\
\hline \multicolumn{2}{|c|}{ Age of Participants } \\
\hline $18-24$ & $25(54.3 \%)$ \\
\hline $25-34$ & $18(39.1 \%)$ \\
\hline \multicolumn{2}{|c|}{ State Lived Before Coming the Pharmacy Program } \\
\hline DC & $4(8.7 \%)$ \\
\hline MD & $12(26.1 \%)$ \\
\hline VA & $9(19.6 \%)$ \\
\hline Others & $19(41.3 \%)$ \\
\hline \multicolumn{2}{|c|}{ Did You Work Before Joining the Pharmacy Program? } \\
\hline No & $2(4.3 \%)$ \\
\hline Yes & $42(91.3 \%)$ \\
\hline \multicolumn{2}{|c|}{ Annual Income } \\
\hline$<\$ 10 \mathrm{k}$ & $17(37.0 \%)$ \\
\hline$\$ 10 \mathrm{~K}-\$ 19 \mathrm{~K}$ & $7(16.3 \%)$ \\
\hline
\end{tabular}




\begin{tabular}{|c|c|}
\hline$\$ 20 \mathrm{~K}-\$ 29 \mathrm{~K}$ & $3(6.5 \%)$ \\
\hline$\$ 30 \mathrm{~K}-\$ 39 \mathrm{~K}$ & $8(17.4 \%)$ \\
\hline$\$ 40 \mathrm{~K}-\$ 49$ & $3(6.5 \%)$ \\
\hline$>\$ 49 \mathrm{~K}$ & $5(10.9 \%)$ \\
\hline \multicolumn{2}{|c|}{ Previous Job Experience } \\
\hline Pharmacy related & $27(58,7 \%)$ \\
\hline Non pharmacy related & $9(19.6 \%)$ \\
\hline Non-Rx related or Health care related & $7(15.2 \%)$ \\
\hline \multicolumn{2}{|c|}{ Previous Job Experience in Years } \\
\hline None & $1(2.2 \%)$ \\
\hline$<1$ year & $7(15.2 \%)$ \\
\hline 1- 3 year & $14(30.4 \%)$ \\
\hline 4 - 5 year & $11(23.9 \%)$ \\
\hline$>5$ year & $11(23.9 \%)$ \\
\hline \multicolumn{2}{|c|}{ Highest Education Earned Before Joining the Pharmacy Program } \\
\hline Some College/Pre-Requisites only & $12(26.1 \%)$ \\
\hline 2 Years College/Associate Degree & $2(4.3 \%)$ \\
\hline 4 years College (BA/BSc) & $26(56.5 \%)$ \\
\hline Masters or Professional Degree & $4(8.7 \%)$ \\
\hline
\end{tabular}

From Table 2, it was observed that over three-quarter of participants $(n=34 ; 75.5 \%)$ were very concerned about employment after graduation while only a small number of participants $(n=10 ; 24.5)$ disagreed about being concerned about employment after graduation. Close to seventy percent of participants $(n=31 ; 68.9 \%)$ believed that the pharmacy related job they desire to work is saturated. Over sixty percent $(n=29 ; 64.4 \%)$ of the students strongly agreed or somewhat agreed that they plan to

Table 2: Descriptive statistics (n (\%)).

\begin{tabular}{|c|c|c|c|c|}
\hline & Strongly Agree & Somewhat Agree & Somewhat Disagree & Strongly Disagree \\
\hline $\begin{array}{l}\text { I am concerned about obtaining employment } \\
\text { after graduation }\end{array}$ & $15(33.3 \%)$ & $19(42.2 \%)$ & $4(8.9 \%)$ & $6(13.3 \%)$ \\
\hline $\begin{array}{l}\text { I believe that the pharmacy school I desire to } \\
\text { work is saturated }\end{array}$ & $14(31.1 \%)$ & $17(37.8 \%)$ & $9(20.0 \%)$ & $4(8.9 \%)$ \\
\hline $\begin{array}{c}\text { I plan or I am currently working during pharmacy } \\
\text { school to increase my chances of gaining } \\
\text { employment after graduation }\end{array}$ & $15(33.3 \%)$ & $14(31.1 \%)$ & $9(20.0 \%)$ & $6(13.3 \%)$ \\
\hline $\begin{array}{l}\text { I am willing to move anywhere and accept } \\
\text { any pharmacy job to obtain employment if job } \\
\text { opportunities are scares }\end{array}$ & $15(33.3 \%)$ & $17(37.8 \%)$ & $6(13.3)$ & $6(13.3)$ \\
\hline $\begin{array}{l}\text { I am not concerned about job opportunities after } \\
\text { graduation because I feel there are enough job } \\
\text { opportunities for pharmacist }\end{array}$ & $4(8.9 \%)$ & $18(40.0 \%)$ & $17(37.8 \%)$ & $5(11.1 \%)$ \\
\hline
\end{tabular}

\section{Discussion}

There are limited number of publications on the effects of concerns about employment of pharmacy students after graduation. The results of this study are comparable of past research. Due to the results of this study and of past research, there is confidence that the information retrieved from the participants of this study were successfully demonstrating the understanding that there are more or are currently working during pharmacy school to increase their chances of gaining employment after graduation. Overwhelming number of students $(n=32 ; 71.1 \%)$ somewhat or strongly agree to the willingness to move anywhere and accept any pharmacy job to obtain employment if job opportunities are scares. Finally, only less than half $(n=22 ; 48.9 \%)$ said that they are not concerned about job opportunities after graduation because they feel there are enough job opportunities for pharmacist [1-4]. 
demographic of the class. There are 34 women and only 10 men in this study. If the numbers for both genders were identical, the results could illustrate different findings. Those who lived outside the DMV area before joining the pharmacy program at Howard University significantly agreed or somewhat agreed that getting an employment after graduation was a concern for them. This might be because they believe the pharmacy field, they desire to work is saturated. They also believe that working during pharmacy school will increase their chances of getting employment after they graduate. Significantly those who had worked or had a job before joining the pharmacy program seem to be very concerned about getting a job after graduation this may be because for most jobs, the more experienced have the higher the chances of employment after graduation. However, about 73 percent of students who have work experience strongly believed that the job market they desire to work in is saturated. That is why more than 70 percent of them are willing to move and accept any job if job opportunities are scares. Half of the participants who had not had a job before coming to Howard strongly disagree that working while in pharmacy school will increase their chances of employment. The limitation of this study is the small sample size, and it only focused on one school of pharmacy and even then, it focuses the first professional year students.

\section{Conclusion}

This study was conducted to have an opinion of pharmacy students during their first year of pharmacy on the possible of

\section{ISSN: 2574-1241}

DOI: 10.26717/BJSTR.2021.36.005790

Bisrat Hailemeskel. Biomed J Sci \& Tech Res

cC (P) This work is licensed under Creative Commons Attribution 4.0 License

Submission Link: https://biomedres.us/submit-manuscript.php employment upon graduation. According to the results there are so many factors that affect students concern about employment when they graduate. Factors such as gender, willingness to move and work experience. Majority of participants were very concerned about employment after graduation and close to seventy percent of participants believed that the pharmacy related job, they desire to work is saturated. Being a female and living outside the DMV area are significant factors for a higher concern for employment. As a result, majority of the students either have a plan to or are currently working during pharmacy school to increase their chances of gaining employment after graduation or are willing to move anywhere and accept any pharmacy job to obtain employment if job opportunities are scares.

\section{References}

1. (2020) FRED Unemployment Rate: Aged 15-24: All Persons for the United States. Federal Reserve Bank of St. Louis; FRED, Federal Reserve Bank of St. Louis.

2. Gardner P (2020) Recruiting Trends. Collegiate Employment Research Institute.

3. Hwang Y (2017) What Is the Cause of Graduates' Unemployment? Focus on Individual Concerns and Perspectives 3(2): 1-10.

4. Brown DL (2013) A looming joblessness crisis for new pharmacy graduates and the implications it holds for the academy. American journal of pharmaceutical education 77(5): 90.

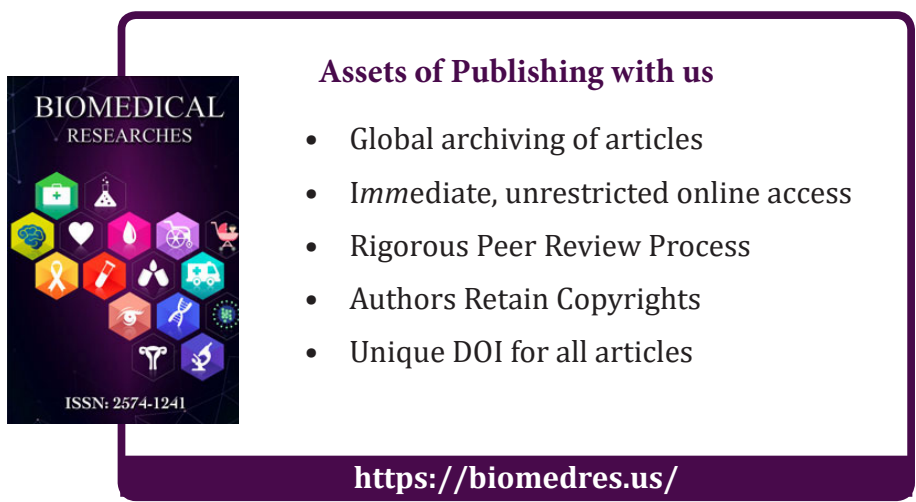

Copyright@ Bisrat Hailemeskel | Biomed J Sci \& Tech Res | BJSTR. MS.ID.005790. 